\title{
A Comparison of Four Processing Tomato Production Systems Differing in Cover Crop and Chemical Inputs
}

\author{
Nancy G. Creamer', Mark A. Bennett, Benjamin R. Stinner, and John Cardina \\ Department of Horticulture and Crop Science and Department of Entomology (BRS), The Ohio State \\ University, 2001 Fyffe Court, Columbus, OH 43210 \\ Additional index words. Lycopersicon esculentum, organic production, hairy vetch, Vicia villosa, rye, Secale cereale, barley, \\ Hordeum vulgare, crimson clover, Trifolium incarnatum, mulch, soil properties, weed management, sustainable agriculture
}

\begin{abstract}
Four tomato production systems were compared at Columbus and Fremont, Ohio: 1) a conventional system; 2) an integrated system [a fall-planted cover-crop mixture of hairy vetch (Vicia villosa Roth.), rye (Secale cereale $\mathbf{L}$.), crimson clover (Trifolium incarnatum $\mathbf{L}$.), and barley (Hordeum vulgare $\mathbf{L}$.) killed before tomato planting and left as mulch, and reduced chemical inputs]; 3) an organic system (with cover-crop mixture and no synthetic chemical inputs); and (4) a noinput system (with cover-crop mixture and no additional management or inputs). Nitrogen in the cover-crop mixture above-ground biomass was $220 \mathrm{~kg} \cdot \mathrm{ha}^{-1}$ in Columbus and $360 \mathrm{~kg} \cdot \mathrm{ha}^{-1}$ in Fremont. Mulch systems (with cover-crop mixture on the bed surface) had higher soil moisture levels and reduced soil maximum temperatures relative to the conventional system. Overall, the cover-crop mulch suppressed weeds as well as herbicide plots, and no additional weed control was needed during the season. There were no differences in the frequency of scouted insect pests or diseases among the treatments. The number of tomato fruit and flower clusters for the conventional system was higher early in the season. In Fremont, the plants in the conventional system had accumulated more dry matter 5 weeks after transplanting. Yield of red fruit was similar for all systems at Columbus, but the conventional system yielded higher than the other three systems in Fremont. In Columbus, there were no differences in economic return above variable costs among systems. In Fremont, the conventional systems had the highest return above variable costs.
\end{abstract}

Ecological problems associated with conventional agricultural practices include soil erosion, contamination of water and soil resources with pesticides and nitrates, and an overdependence on fossil fuel (National Research Council, 1989). Thus, there is interest in developing agricultural systems that rely less on fossilfuel based inputs and more on biological processes to achieve similar productivity. Winter annual cover crops can enhance biological processes and potentially reduce fossil-fuel based inputs. They are seeded in late summer or early fall, overwinter, and then resume rapid growth in the spring. Winter annual cover crops can be an important source of biologically fixed nitrogen (Hoyt and Hargrove, 1986), help control soil erosion (Flach, 1990), improve soil physical properties (McVay et al., 1989), reduce nitrate leaching losses (Stivers and Shennan, 1989), add organic matter to the soil (Blevins et al., 1977), influence pest life cycles (Phatak et al., 1990), and suppress weeds (Teasdale, 1993).

One method of managing winter cover crops in the spring is to kill them and leave their residue as a surface mulch. The subse-

Received for publication 12 July 1995. Accepted for publication 19 Jan. 1996 Journal article no. 185-95, Ohio Agricultural Research and Development Center, Ohio State Univ. This paper is a portion of a thesis submitted by Nancy Creamer in partial fulfillment of $\mathrm{PhD}$ requirements at Ohio State Univ. This research was supported in part by grants from the USDA Sustainable Agriculture Research and Education Program, the Mid-America Food Processors Association, and Virginia Stranahan. We extend our appreciation to Mac Riedel and Debbie Hamner, who assisted with disease assessment, and to Barry Plassman, Randall Wood, and the Ohio State Univ. Agricultural Engineering Dept. for contributing to the design and construction of the undercutter. Mention of a trademark, proprietary product, or vendor does not constitute a product guarantee or warranty by Ohio State Univ. and does not imply its approval to the exclusion of other products or vendors. The cost of publishing this paper was defrayed in part by the payment of page charges. Under postal regulations, this paper therefore must be hereby marked advertisement solely to indicate this fact.

${ }^{1}$ Former Ohio State Univ. graduate student, currently assistant professor in the Horticultural Science Dept., North Carolina State Univ., Vernon G. James Research and Extension Center, 207 Research Station Rd., Plymouth, NC 27962. quent crop is then no-till (NT) planted into the residue. Some general benefits of conservation tillage in killed cover-crop mulches are less time to prepare fields for planting, higher water infiltration and retention, increases in organic matter, and improved soil physical and chemical properties (Hoyt et al., 1994).

Cover-crop residues remaining on the soil surface can suppress weeds by modifying light, soil temperatures, and soil moisture (Teasdale and Mohler, 1993), and by allelopathy, a direct or indirect harmful effect produced in one plant through toxic chemicals released into the environment by another (Rice, 1974). This definition includes chemicals produced by actinomycetes, algae, fungi, and other microbes that may associate with the plants in the rhizosphere (Putnam, 1988).

Diseases can be reduced, enhanced, or unaffected in cover-crop conservation tillage systems depending on the type of inoculum. If the disease inoculum survives best on surface residue, there can be increased disease. In fact, burying crop residue has been a suggested cultural control technique for many diseases (Merriman et al., 1979). By leaving plant debris on the surface, pathogens may survive until the next crop is planted (Fawcett, 1987). Many diseases are associated with surface residue including root diseases, as well as fungal and bacterial blights (Boosalis and Cook, 1973). On the other hand, conditions for biological control of plant pathogens may be enhanced by surface residue (Phillips, 1984). Organic matter is often beneficial in increasing populations of saprophytic fungi and bacteria that antagonize and parasitize root pathogens (Sumner et al., 1986).

Cover crops unrelated to the previous crop may help break disease cycles, whereas residue of a related previous crop could enhance disease cycles. The type of cover crop may also influence diseases. For example, tomatoes following legumes resulted in increased root disease (Sumner et al., 1986). The cover-crop residue will also modify soil moistures and temperatures that can stress crops and affect their susceptibility to disease. 
A limited amount of research has examined the effect of cover crops on insect incidence in vegetable crops. Cover crops can attract both beneficial insects and harmful pests to cropping systems (Altieri and Letourneau, 1982; Andow, 1988). The effect on insect populations will depend on the cover crop, the cash crop, and other environmental factors. A rye cover with tomatoes decreased tomato fruitworm damage, but increased stink bug damage (Roberts and Cartwright, 1991). In general, there were fewer insects and related damage in plots covered with rye in cabbage, sweet corn, and tomatoes. Cover crops can attract predators into a field to feed on other insects, nectar, or pollen. As the cover crops die, the predators can help to control pests in subsequent or adjacent crops. Particularly high densities of the generalistic predator bigeyed bugs (Georcoris punctipes) were found in late spring on several different types of clovers (Bugg et al., 1990). Another study suggests that predation of fall armyworm in cantaloupes increased when bigeyed bugs moved from dying cover crops onto adjoining cantaloupe plants (Bugg et al., 1991). Cover crops can also attract pests, which can cause damage to subsequent or nearby crops. In California, movement of Lygus spp. (Hemiptera: Miridae) from mown alfalfa to cotton causes economic damage (Stern et al., 1967).

The few studies on NT tomato production systems have reported contradictory results. Yield of seeded processing tomatoes grown in a NT system were equal to those grown with conventional tillage (Beste, 1973), but yields of marketable staked tomatoes tended to decrease as tillage intensity decreased (Doss et al., 1981). Staked tomato yields of conventionally produced tomatoes were either higher than or comparable to yields in NT systems (Shelby et al., 1988). Staked tomatoes NT planted into a killed mulch of hairy vetch yielded higher than conventionally grown tomatoes (Abdul-Baki and Teasdale, 1993).

Mixtures of cover-crop species rather than monocultures can be used to optimize some of the benefits associated with cover-crop use. By establishing a mixture, it is possible to increase the amount of above-ground biomass and N (Ofori and Stern, 1987), increase the amount of $\mathrm{N}$ fixed by legumes (Agboola and Fayemi, 1972), aid in the overwintering of some cover crops (Exner and Cruse, 1993), facilitate decomposition more timed with crop needs by moderating $\mathrm{C}: \mathrm{N}$ ratios, and increase weed suppression.

This research examines the use of winter annual cover crops as a means of producing processing tomatoes more efficiently with regard to capital and resources. The objectives of this study were to compare four processing tomato production systems that varied in their level of chemical inputs, and presence of cover crops. Cover-crop growth and yield; tomato plant growth, development, yield, and quality; soil nitrate, moisture and temperatures; weed, insect, and disease levels; and the economics of the four systems were evaluated.

\section{Materials and Methods}

In 1991-92, 13 cover-crop mixtures were screened at two Ohio locations to find a species mix that established quickly, gave adequate erosion control, was winter hardy, contributed sufficient $\mathrm{N}$ for subsequent crops, had minimal $\mathrm{N}$ immobilization after cover-crop kill, could be killed by mechanical methods, and had high weed control potential. Based on species performance in the field screening the mixture used in this experiment was a hairy vetch, rye, crimson clover, and barley combination seeded at 22.5, $27,11.2$, and $27 \mathrm{~kg} \cdot \mathrm{ha}^{-1}$, respectively.

Experiments were conducted in 1992-93 at the Ohio State Univ. (OSU) Horticulture Farm, Columbus, on a Miami silt loam with a pH of 6.8 , and at the OSU/OARDC Vegetable Crops Branch, Fremont, Ohio, on a Colwood fine sandy loam with a $\mathrm{pH}$ of 6.1. The Fremont soil is more typical of those used for processing tomato production in Ohio. The four processing tomato production systems were as follows.

Conventional production (no cover crop). Preplant herbicides were trifluralin [2,6 dinitro- $N, N$-dipropyl-4-(trifluoromethyl) benzenamine] in Columbus and Fremont at $0.56 \mathrm{~kg}$ a.i./ha and metribuzin [4-amino-6-tert-butyl-3-(methylthio)-a5-triazin-5(4H)one] in Fremont at $0.27 \mathrm{~kg}$ a.i./ha. A preplant fertilizer $(78 \mathrm{~N}-$ $157 \mathrm{P}-157 \mathrm{~K} \mathrm{~kg} \cdot \mathrm{ha}^{-1}$ ) was applied immediately before planting. Insecticides were used as necessary, based on field scouting, and carbaryl [1-naphthyl $N$-methylcarbamate] was applied at $2.24 \mathrm{~kg}$ a.i./ha once in Fremont. Fungicides were applied based on the TOMCAST disease forecasting system that takes into account daily moisture and temperature readings (Pitblado, 1988). Seven fungicide applications were necessary in Columbus and 5 in Fremont [copper hydroxide at $2.04 \mathrm{~kg}$ a.i./ha and chlorothalonil (etrachloroisophthalonitrile) at $2.52 \mathrm{~kg}$ a.i./ha].

Integrated production (with cover crop). Postemergence herbicides were to be applied if necessary, however it was not necessary. Preplant fertilizer was applied at half the conventional rate $(39 \mathrm{~N}-$ $78 \mathrm{P}-78 \mathrm{~K} \mathrm{~kg} \cdot \mathrm{ha}^{-1}$ ). Insecticides were applied based on scouting (2.24 kg a.i./ha carbaryl was applied once in Fremont). Fungicides were applied based on TOMCAST as above, but at half the rates listed in the conventional treatment.

Organic production (with cover crop). Management was based on the Ohio Ecological Food and Farming Association's (OEFFA) organic production standards (OEFFA, 1992). Mechanical weed control was to be used if necessary, however, it was not necessary. Three foliar fertilizer applications of fish extract $(0.07 \mathrm{~N}-0.008 \mathrm{P}-$ $0.03 \mathrm{~K} \mathrm{~kg} \cdot \mathrm{ha}^{-1}$ ) were applied once every 2 weeks for the first 6 weeks of production. Seaweed powder $\left(0.007 \mathrm{~N}-0 \mathrm{P}-0.02 \mathrm{~K} \mathrm{~kg} \cdot \mathrm{ha}^{-1}\right)$ was combined with the fish extract for the last fertilizer application. Insect control was based on scouting, and Bacillus thuringiensis (0.7 1 a.i./ha) was applied once in Fremont. No fungicides were applied.

No additional inputs (with cover crop). After transplanting the tomatoes, there were no additional inputs or management. For the three treatments with cover crops, the mixture of rye, barley, hairy vetch, and crimson clover was planted on raised beds $(1.5 \mathrm{~m}$ wide $\times 15.25 \mathrm{~m}$ long) on 2 Sept. (Columbus), and on 25 Aug. 1992 (Fremont). Raised beds were used because nearly all processing tomato production in the midwestern United States and Ontario relies on this crop management system. Seed was broadcast by hand on the surface of the beds, and lightly raked in.

On 26 May (Columbus) and 1 June 1993 (Fremont), the cover was mechanically killed with an undercutter and left as a surface mulch. Two blades at 45-degree angles from the direction of travel with a 15 degree pitch, cut approximately $5 \mathrm{~cm}$ deep. A mounted rolling harrow was attached to the undercutter to lay the cover crop flat on the surface after being cut (Creamer et al., 1995). On the same day, processing tomatoes (' $\mathrm{OH} 8245$ ') were mechanically transplanted into the mulch. A NT transplanter (RJ Equipment, Blenheim, Ontario) was used for transplanting, and was able to successfully cut slots in the 10- to $15-\mathrm{cm}$-thick mulch. Twin rows were planted $40 \mathrm{~cm}$ apart, with $38 \mathrm{~cm}$ within row spacing.

Cover-crop measurements. On 24 May (Columbus) and 1 June (Fremont), 1- $\mathrm{m}^{2}$ biomass samples from each of four replications were cut at the soil surface, separated into component species, dried at $65 \mathrm{C}$ for a minimum of $48 \mathrm{~h}$, and weighed to determine above-ground biomass. Samples of each cover-crop species were coarsely ground with a Wiley mill. Representative subsamples 
Table 1. Species composition, above-ground biomass (AGB), C : N ratios, and total $\mathrm{N}$ in cover crop mix at Columbus and Fremont, Ohio, 1993.

\begin{tabular}{|c|c|c|c|c|c|c|c|c|}
\hline & \multicolumn{4}{|c|}{ Columbus } & \multicolumn{4}{|c|}{ Fremont } \\
\hline & Percent in mix & AGB $\left(\mathrm{kg} \cdot \mathrm{ha}^{-1}\right)$ & $\mathrm{C}: \mathrm{N}$ & Total N $\left(\mathrm{kg} \cdot \mathrm{ha}^{-1}\right)$ & Percent in mix & AGB $\left(\mathrm{kg} \cdot \mathrm{ha}^{-1}\right)$ & $\mathrm{C}: \mathrm{N}$ & Total $\mathrm{N}\left(\mathrm{kg} \cdot \mathrm{ha}^{-1}\right)$ \\
\hline Hairy vetch & 57 & 5500 & 15.9 & 160 & 54 & 7810 & 13.2 & 265 \\
\hline Rye & 28 & 2650 & 37.2 & 35 & 28 & 3940 & 36.7 & 50 \\
\hline Barley & 10 & 950 & 26.4 & 15 & 7 & 990 & 27.0 & 15 \\
\hline Crimson clover & 5 & 470 & 17.5 & 10 & 11 & 1550 & 20.5 & 30 \\
\hline Total for mixture & 100 & 9570 & $23.0^{\mathrm{z}}$ & 220 & 100 & 14290 & $21.6^{\mathrm{z}}$ & 360 \\
\hline
\end{tabular}

${ }^{\mathrm{z}}$ Based on percentage species composition in mixture.

were reground to a fine powder with a Brinkmann 2 MI centrifugal grinding mill (200- $\mu \mathrm{m}$ mesh screen). Carbon and nitrogen were determined based on the Dumas method (Nelson and Summers, 1982), with a NA 1500 Series 2 analyzer (Carlo Erba Instruments, Milano, Italy).

Tomato plant measurements. Tomato survival was evaluated 2 weeks after transplanting. Plant height and stem diameters were measured 2 and 5 weeks after transplanting. The number of flower and fruit clusters were counted 1 and 2 months after transplanting to evaluate earliness of fruit set. Plants were harvested at the soil line 1 month after transplanting, dried at $65 \mathrm{C}$ for at least $72 \mathrm{~h}$ and weighed to determine above-ground dry weights. The fourth or fifth leaflet from the growing tip of 20 plants per plot was sampled at early fruit set (Jones and Case, 1990) for nutrient analysis on 8 July (Columbus), and 13 July (Fremont). The leaves were dried, ground, and analyzed for percentage N, P, and K by Mid-West Labs (Omaha, Neb.) Tomatoes were hand-harvested on 26 Aug. (Columbus) and 8 Sept. (Fremont) on 3-m lengths of bed and separated into red, green, rotten, and cull fruit categories. Following harvest, random samples of tomatoes were blended under vacuum suction to evaluate tomato quality, including color (Agtron ME-5M colorimeter), $\mathrm{pH}$, and soluble solids (American Optic Abbey Refractometer).

Soil and mulch measurements. Soil nitrate levels were measured every 2 weeks following transplanting. Ten $15-\mathrm{cm}$-deep soil cores were bulked and sieved through 2-mm screens, extracted with $2 \mathrm{M} \mathrm{KCl}$ (shaken for $1 \mathrm{~h}$ ), and filtered (Keeney and Nelson, 1982). The leachates were kept at 4C until analyzed (within 1 week of sampling) on a Lachate autoanalyzer. Soil moisture was determined gravimetrically (Gardner, 1986) every two weeks from 15cm-deep soil cores (10 bulked per plot). Soil temperatures were taken with $\mathrm{min} / \mathrm{max}$ soil thermometers placed $10 \mathrm{~cm}$ deep in the plots. Temperatures from three replications each in the mulched and nonmulched plots were measured about every 7 days through July.

Weed, insect, and disease measurements. Weed densities (broadleaves and grasses) were counted in three $0.5-\mathrm{m}^{2}$ areas per plot 2 and 4 weeks after planting. Above-ground weed biomass was collected from $0.5-\mathrm{m}^{2}$ areas (4 per plot) 6 and 12 weeks after planting. Weeds were separated by species, dried at $65 \mathrm{C}$ for at least $48 \mathrm{~h}$, and weighed. A 2.4-m section of each conventional plot was not treated with herbicides, and functioned as check plots. Only annual weeds were measured in this study, and the few patchy spots of perennial weeds were periodically hand-weeded.

The common insect pests of tomatoes in Ohio were scouted on a weekly basis. These included aphids (primarily Myzus persicae and Macrosiphyn euphorbiae), flea beetles (primarily Epitrix hirtipennis), tomato fruitworm (Helicoverpa zea), tomato hornworm (Manduca quinquemaculata), and Colorado potato beetle (Leptinotarsa decemlineata). Five plants per plot were randomly selected for scouting, and thresholds calculated by the Ohio integrated pest management project were used to determine pest management decisions.

Visual scouting for early blight (Alternaria solani) and septoria leaf blight (Septoria lycopersici) was conducted in mid-July and early August. At harvest, diseased fruits were sorted to quantify the incidence of anthracnose (Colletotrichum coccodes), ground rot (Pythium spp.), bacterial speck (Pseudomonas syringae pv. tomato), and bacterial spot (Xanthomonas campestris pv. vesicatoria).

Economic analysis. An economic analysis of variable costs to compare the four systems (inputs, yield, and price received per ton) was done. Analysis of fixed costs was beyond the scope of this project and therefore was not done. Costs for purchased inputs where available, were taken from the OSU Dept. of Agricultural Economics 1993 processing tomato production budget, or directly from suppliers. Custom application charges were from the OSU Dept. of Agricultural Engineering's custom rate guide for Ohio. The $15 \%$ differential in price between conventionally grown tomatoes and certified organically grown tomatoes is what is currently available to certified organic producers for processing tomatoes (John Hirzel, Hirzel Canning Co. and Farms, Toledo, Ohio, personal communication).

Table 2. Influence of four processing tomato production systems on percent leaf tissue N-P-K at early fruit set ( 8 July at Columbus and 13 July at Fremont, Ohio) for processing tomato 'OH8245'.

\begin{tabular}{|c|c|c|c|c|c|c|}
\hline \multirow[b]{2}{*}{ System } & \multicolumn{3}{|c|}{ Columbus } & \multicolumn{3}{|c|}{ Fremont } \\
\hline & $\mathrm{N}$ & $\mathrm{P}$ & $\mathrm{K}$ & $\mathrm{N}$ & $\mathrm{P}$ & $\mathrm{K}$ \\
\hline \multicolumn{7}{|c|}{ Percentage } \\
\hline Conventional & $4.96 \mathrm{H}^{\mathrm{z}}$ & $0.50 \mathrm{~S}$ & $2.41 \mathrm{D}$ & $5.11 \mathrm{H}$ & $0.38 \mathrm{~S}$ & $2.73 \mathrm{~L}$ \\
\hline Integrated & $4.01 \mathrm{~L}$ & $0.62 \mathrm{H}$ & $2.57 \mathrm{D}$ & $4.87 \mathrm{H}$ & $0.42 \mathrm{~S}$ & $2.72 \mathrm{~L}$ \\
\hline Organic & $3.87 \mathrm{~L}$ & $0.59 \mathrm{H}$ & $2.36 \mathrm{D}$ & $5.02 \mathrm{H}$ & $0.39 \mathrm{~S}$ & $2.53 \mathrm{~L}$ \\
\hline No input & $3.66 \mathrm{~L}$ & $0.59 \mathrm{H}$ & $2.41 \mathrm{D}$ & $5.01 \mathrm{H}$ & $0.39 \mathrm{~S}$ & $2.49 \mathrm{~L}$ \\
\hline $\operatorname{LSD}_{(0.05)}$ & 0.39 & 0.03 & NS & NS & NS & NS \\
\hline
\end{tabular}


Table 3. Influence of four processing tomato production systems on tomato ('OH8245') red fruit yield and quality measurements ( $\mathrm{pH}$, soluble solids, and color), in Columbus and Fremont, Ohio, 1993.

\begin{tabular}{|c|c|c|c|c|c|c|c|c|}
\hline \multirow[b]{2}{*}{ System } & \multicolumn{4}{|c|}{ Columbus } & \multicolumn{4}{|c|}{ Fremont } \\
\hline & $\begin{array}{l}\text { Red fruit } \\
\left(\mathrm{Mg} \cdot \mathrm{ha}^{-1}\right)\end{array}$ & $\mathrm{pH}$ & $\begin{array}{c}\text { Soluble solids } \\
(\%)\end{array}$ & $\begin{array}{l}\text { Agtron } \\
\text { ME-5M }\end{array}$ & $\begin{array}{l}\text { Red fruit } \\
\left(\mathrm{Mg} \cdot \mathrm{ha}^{-1}\right)\end{array}$ & $\mathrm{pH}$ & $\begin{array}{c}\text { Soluble solids } \\
(\%)\end{array}$ & $\begin{array}{l}\text { Agtron } \\
\text { ME-5M }\end{array}$ \\
\hline Conventional & 35.9 & 3.98 & 5.40 & 39.25 & 65.5 & 4.10 & 3.38 & 40.75 \\
\hline Integrated & 29.2 & 3.93 & 5.60 & 49.50 & 44.1 & 4.00 & 3.90 & 41.75 \\
\hline Organic & 26.1 & 3.95 & 5.45 & 43.25 & 34.8 & 4.08 & 3.85 & 46.00 \\
\hline No input & 25.3 & 3.85 & 5.35 & 44.00 & 36.4 & 4.08 & 3.75 & 53.25 \\
\hline $\operatorname{LSD}_{(0.05)}$ & NS & NS & NS & NS & 13.9 & NS & 0.35 & NS \\
\hline
\end{tabular}

The experimental design was a randomized complete block with four replications and four production systems at two locations. Data were subjected to analysis of variance, and LSD tests were used to separate means (Wilkinson, 1990).

\section{Results and Discussion}

Cover-crop variables. Cover crops were killed when the hairy vetch was at midbloom. The rye, crimson clover, and barley were more mature than the hairy vetch, but had not yet produced viable seed. There was no regrowth of the crimson clover and barley, and very little of the hairy vetch and rye. Total above-ground biomass (AGB) was substantial at both sites, but was $49 \%$ greater at Fremont (Table 1). This was probably due to better growing conditions in Fremont, and an additional 1-week growing period in the spring. Wagger (1987) found that substantial dry matter and $\mathrm{N}$ content were forfeited when cover crops were killed early rather than late. The $\mathrm{C}: \mathrm{N}$ ratio of the mixture (based on the percent composition of the mixture and the $\mathrm{C}: \mathrm{N}$ ratio of each species) was within the optimal 20C:1N to 30C:1N ratio for limited immobilization (Kommedahl, 1984) and release of N (Allison, 1966). Total $\mathrm{N}$ in the AGB was $220 \mathrm{~kg} \cdot \mathrm{ha}^{-1}$ in Columbus, and $360 \mathrm{~kg} \cdot \mathrm{ha}^{-1}$ in Fremont (Table 1). As a general rule, approximately half of the nitrogen in aboveground cover-crop biomass is mineralized during the following growing season (Broadbent, 1984).

Tomato measurements. Tomatoes growing in the mulch looked vigorous throughout the season. Transplant survival averaged $>95 \%$ at both sites; however, additional care was neces-

Fig. 1. Influence of four processing tomato production systems on soil nitrate levels in the top $15 \mathrm{~cm}$, measured every 2 weeks in Columbus and Fremont, Ohio, 1993.

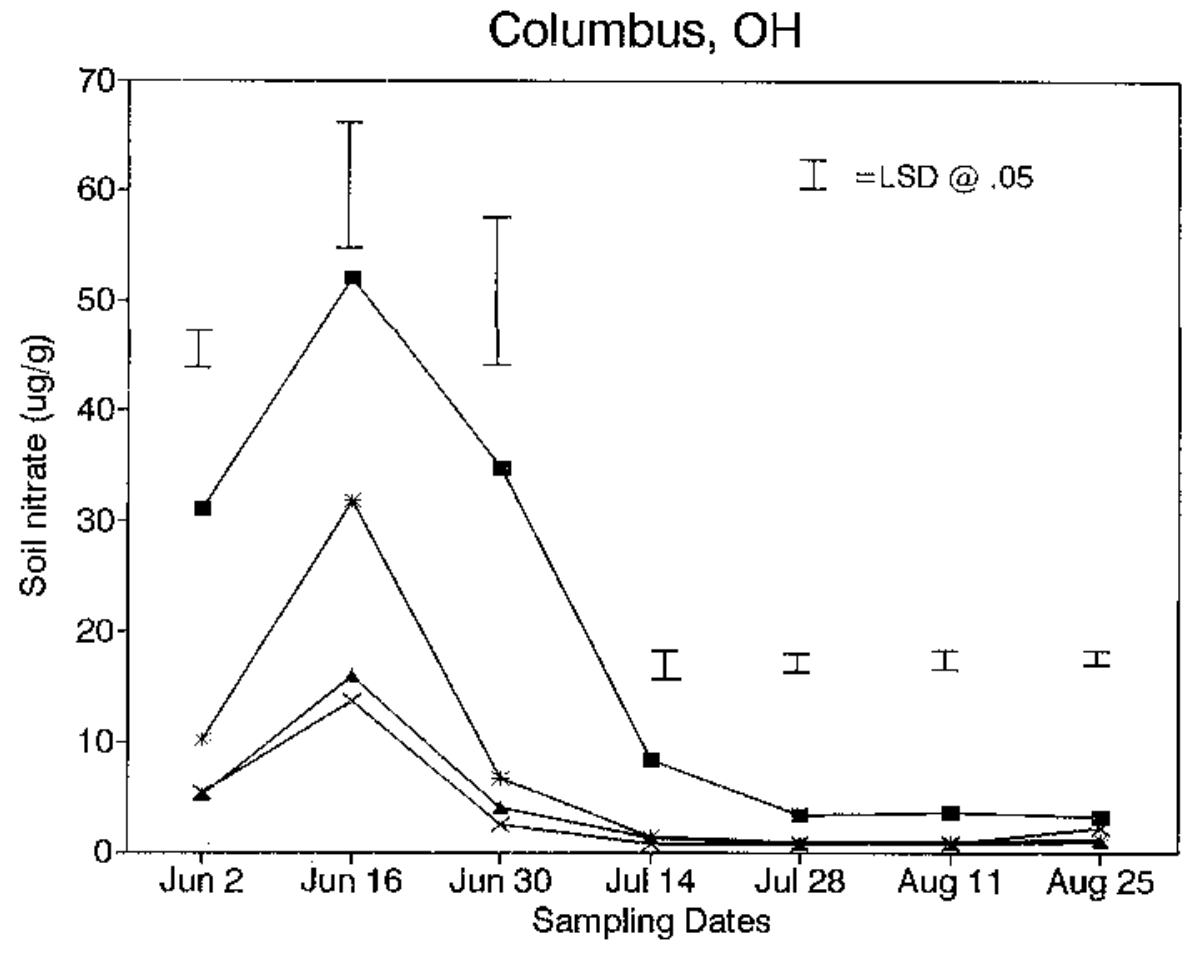

Fremont, $\mathrm{OH}$

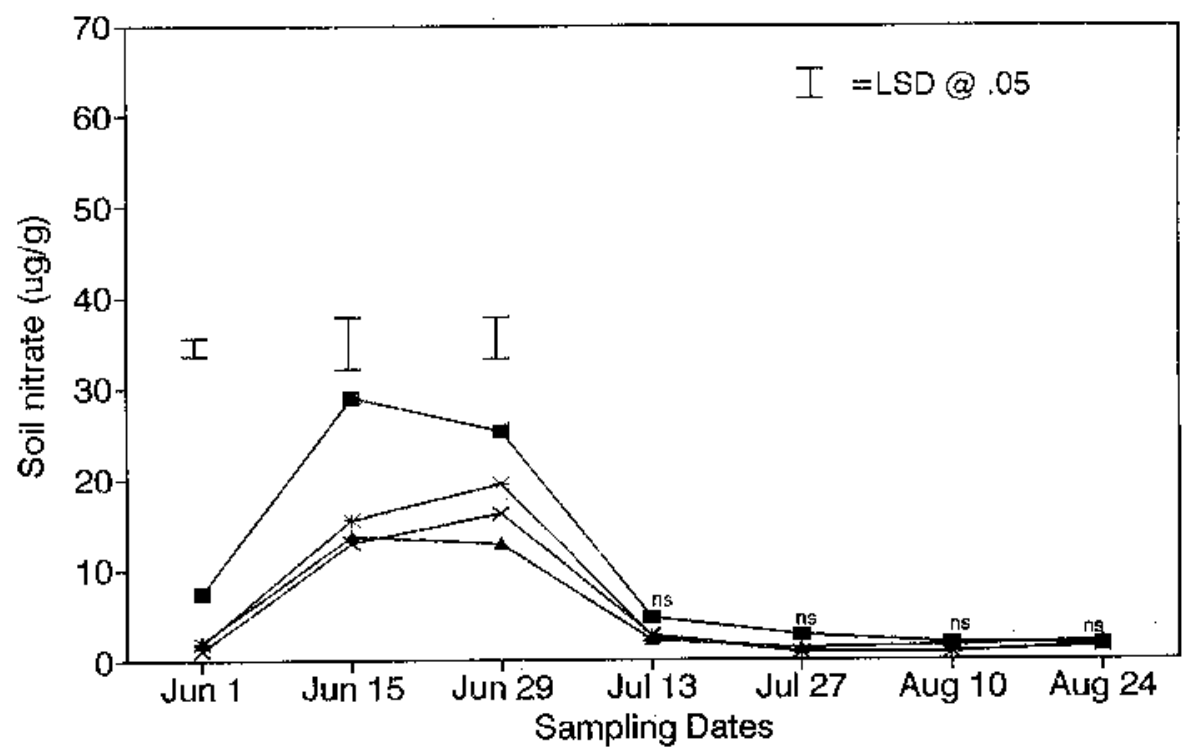

- Conventional $\rightarrow$ Integrated $\rightarrow$ Organic 
Table 4. Rainfall totals (cm) from 1 May-15 Sept. 1993, and long-term averages ( $>80$ years) in Columbus and Fremont, Ohio.

\begin{tabular}{lccccc}
\hline \hline & \multicolumn{2}{c}{1993} & & \multicolumn{2}{c}{ Long-term avg } \\
\cline { 2 - 3 } \cline { 5 - 6 } Date & Columbus & Fremont & & Columbus & Fremont \\
\hline 1-15 May & 3.10 & 0.43 & & 4.90 & 3.91 \\
16-31 May & 2.49 & 2.03 & & 5.63 & 5.23 \\
1-15 June & 5.92 & 6.50 & & 5.28 & 5.54 \\
16-30 June & 9.37 & 4.65 & & 5.56 & 4.60 \\
1-15 July & 10.41 & 3.23 & & 5.79 & 5.38 \\
16-31 July & 2.57 & 0.25 & & 5.33 & 4.55 \\
1-15 Aug. & 1.65 & 1.22 & & 4.70 & 4.24 \\
16-31 Aug. & 0.58 & 0.69 & & 4.49 & 4.57 \\
1-15 Sept. & 3.58 & 2.64 & & 3.78 & 3.90 \\
\hline
\end{tabular}

\section{Columbus, $\mathrm{OH}$}

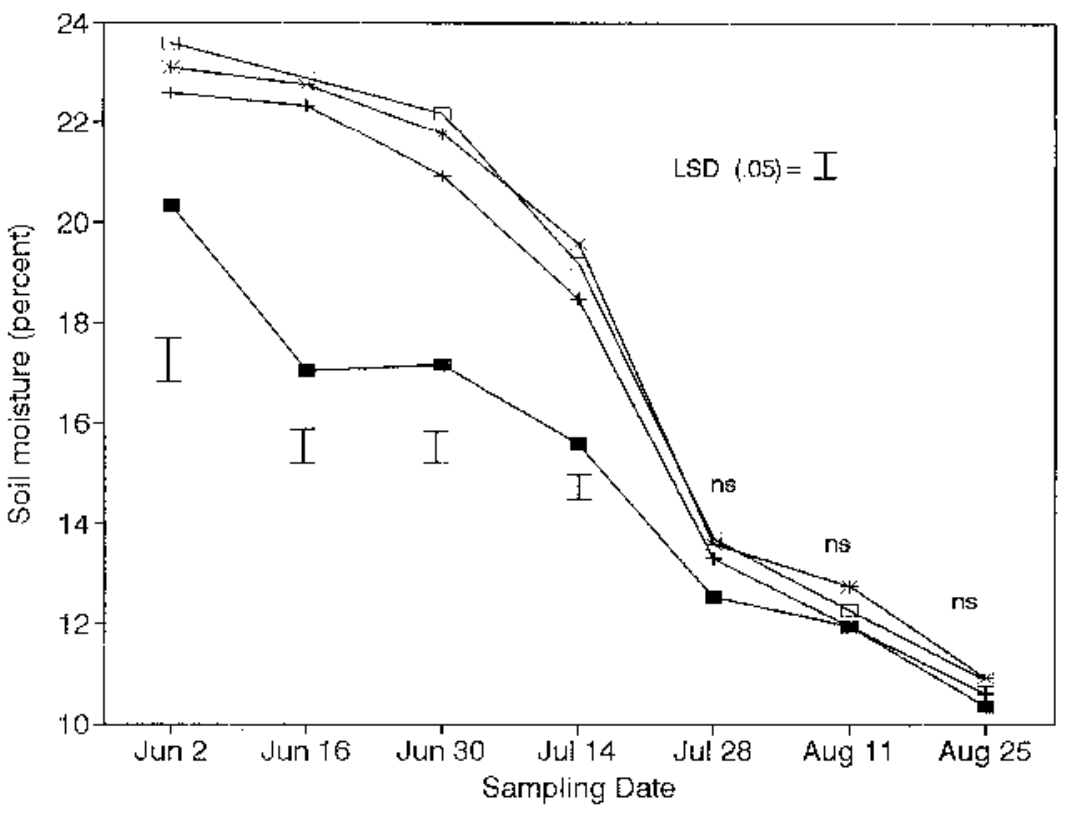

Fremont, $\mathrm{OH}$

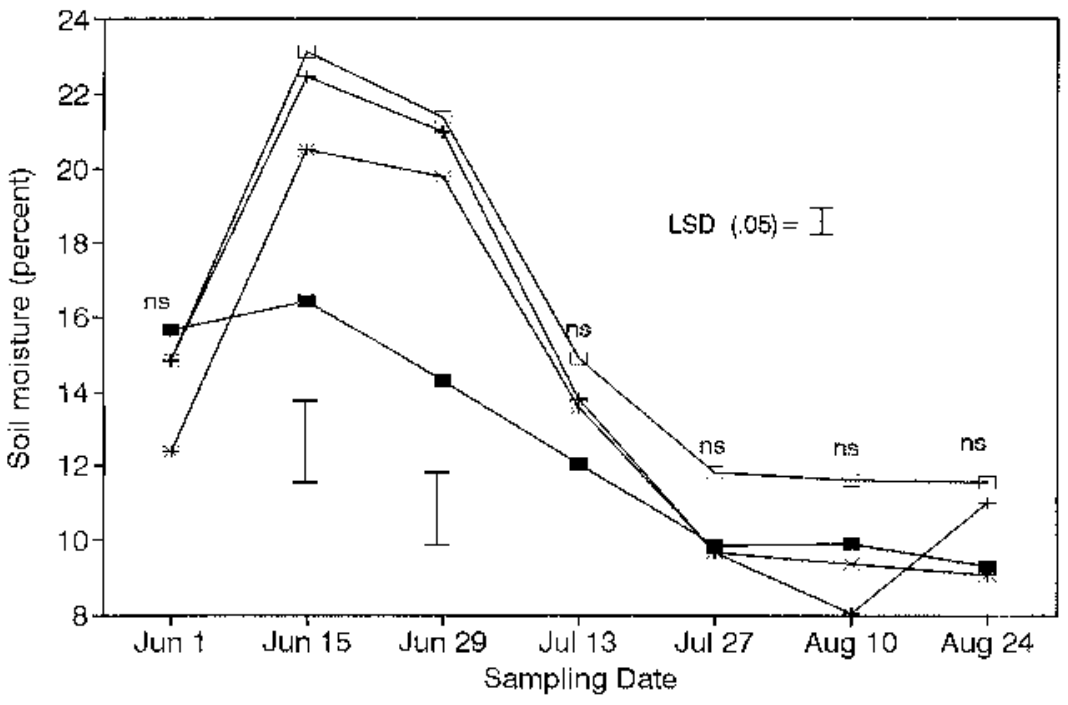

$\rightarrow-$ Conventional -trm Integraled sary to insure that soil was well packed around the transplants in the cover-crop plots. With further adjustment to the transplanter, this problem could have been eliminated. There were no statistical differences in stem diameter $(\mathrm{x}=10 \mathrm{~mm}$ at Columbus; $\mathrm{x}=12 \mathrm{~mm}$ at Fremont) or plant height $(\mathrm{x}=29 \mathrm{~cm}$ at Columbus; $\mathrm{x}=42 \mathrm{~cm}$ at Fremont) 5 weeks after transplanting, though the plants at Fremont were taller. The number of fruit and flower clusters for the conventional system $(\mathrm{x}=8.9$ at Columbus; $\mathrm{x}=11.5$ at Fremont $)$ were higher than the other systems $(x=6.8$ at Columbus; $x=6.2$ at Fremont) the first sampling date at both locations. By the second sampling date, clusters in the other systems were equivalent to those in the conventional system $(\mathrm{x}=25.6$ at Columbus; $\mathrm{x}=25.0$ at Fremont). Other studies have shown a delay in growth and development in NT cover-crop production systems. Price and Baughan (1987) showed that fresh market tomato plants began growth sooner after transplanting in conventional tilled plots, and also had a more rapid growth rate for an initial 40 days than in NT plots. Similar delays have been found in corn and squash (Fortin and Pierce, 1991; NeSmith et al., 1994).

There were no differences in tomato plant dry weights at Columbus 35 days after transplanting (data not shown). In Fremont, the plants in the conventional system were larger (16 g/ plant) than in the other systems, and the plants in the integrated system $(10 \mathrm{~g} /$ plant $)$ were larger than those in the organic and no-input systems (8 and $7.5 \mathrm{~g} / \mathrm{plant}$ respectively).

In Columbus, there was more tissue $\mathrm{N}$ and less tissue $\mathrm{P}$ in the conventional system than the other systems (Table 2). The conventional system had high levels of $\mathrm{N}$ and sufficient levels of $\mathrm{P}$, while the other systems had low $\mathrm{N}$ and high $\mathrm{P}$ levels. There were no differences in $\mathrm{K}$ levels. In Fremont, there were no differences in N, P, or $K$ levels. Nitrogen levels were high, $P$ levels were sufficient, and $\mathrm{K}$ levels were low.

Yields of red fruit were not different among systems in Columbus, but in Fremont, the conventional system had higher yields (Table 3 ). Overall, plots in Fremont had higher yields compared to Columbus, partially explained by soil type, and weather differences. State average yields of processing tomatoes in Ohio are about $53 \mathrm{Mg} \cdot \mathrm{ha}^{-1}$. There were no differences between systems in the amount of green or rotten fruit at either site (data not shown). Plants from the conventional system at Fremont were larger, but there were no differences in the number of flower clusters at 2 months after planting. Flower clusters were more concentrated on the smaller plants, but this did not compensate in yield for the reduced plant dry weight. Though fruit tended to be larger in the conventional system in Fremont, the difference was not significant (data not shown). There were few differences in tomato fruit quality measurements at either loca-

Fig. 2. Influence of four processing tomato production systems on percentage soil moisture in the top $15 \mathrm{~cm}$, measured every 2 weeks in Columbus and Fremont, Ohio, 1993. 


\section{Columbus, $\mathrm{OH}$}

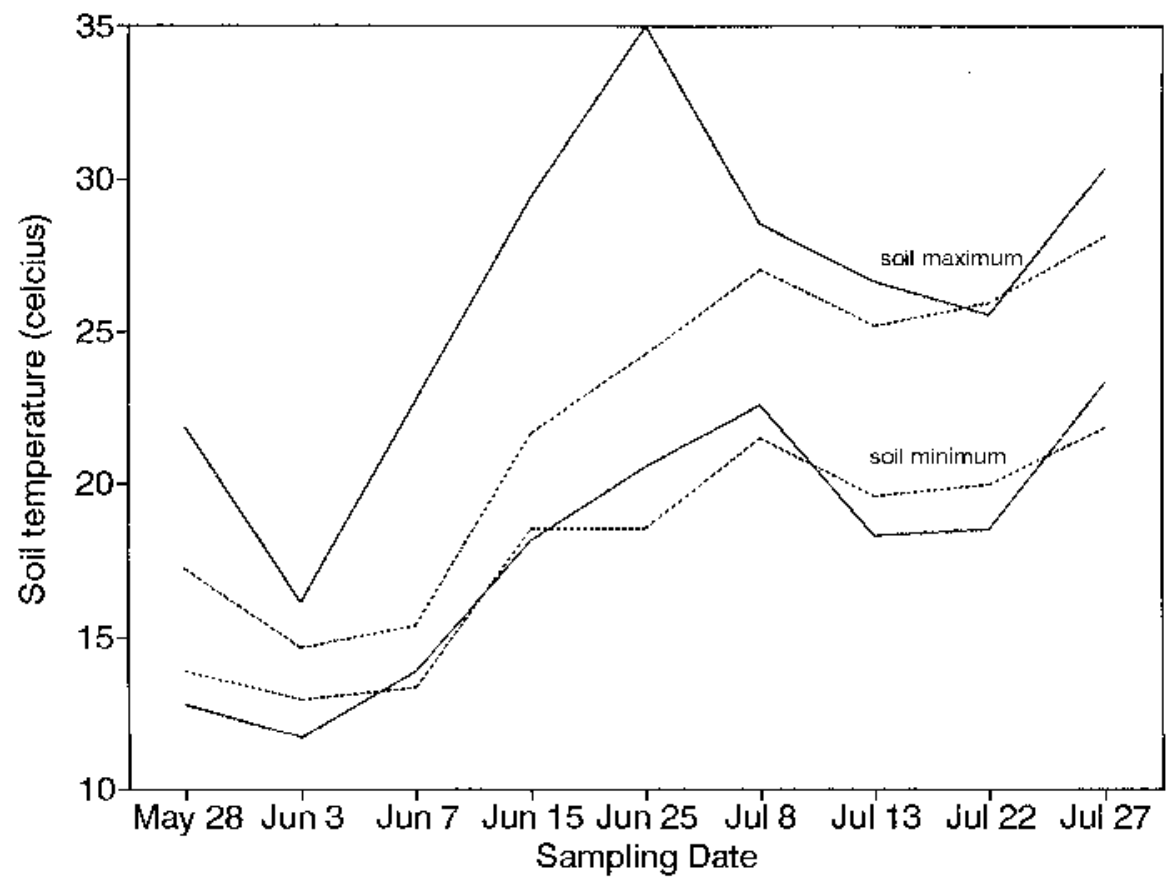

Fremont, $\mathrm{OH}$

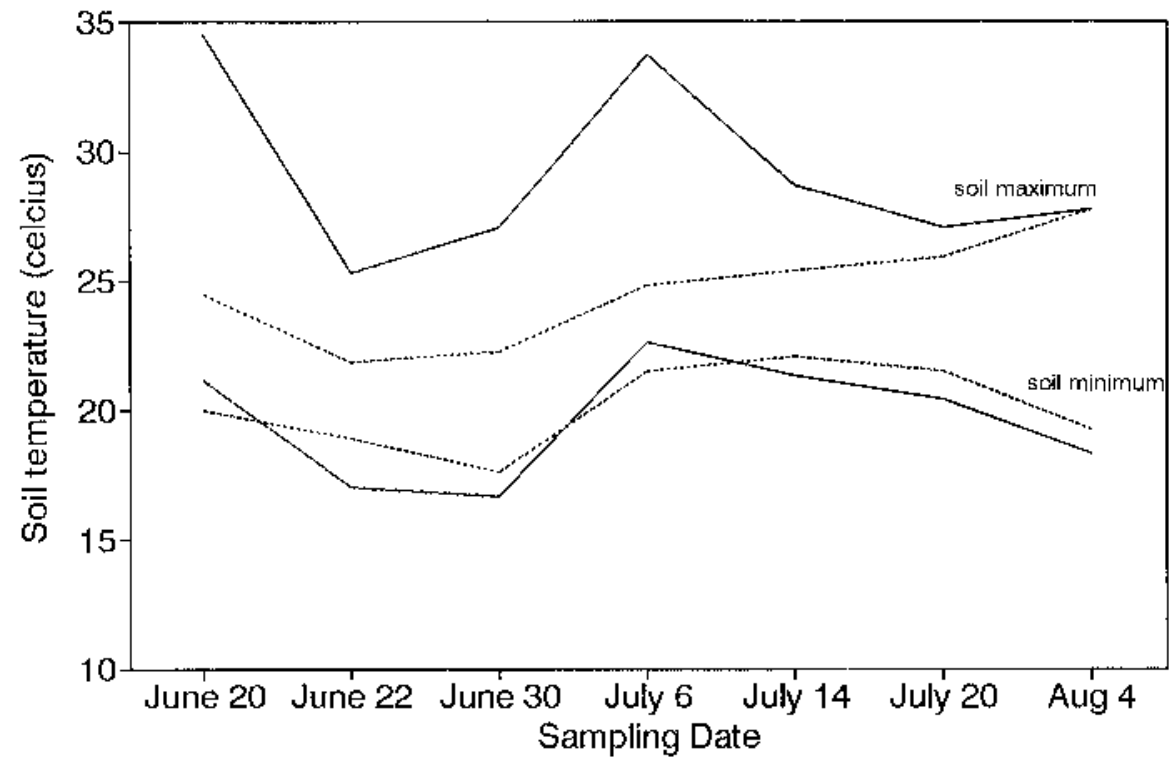

Fig. 3. Soil temperatures at $10 \mathrm{~cm}$ of the cover-crop mulch plots (integrated, organic, and no-input systems) and the conventional unmulched plots in Columbus and Fremont, Ohio, 1993.

tion (Table 3). At Fremont fruit soluble solids were lower in conventional systems than in the other systems, while soluble solids at Fremont were less than in Columbus. Relationships between soluble solids have been found to be negatively correlated with yield (Berry et al, 1988; Stevens and Rudich, 1978), which is consistent with high tonnage but lower soluble solids in Fremont than in Columbus.

Soil and mulch variables. Soils from the conventional system in Columbus generally had higher soil nitrate levels throughout the growing season compared with the other systems (Fig. 1). In Fremont, the conventional system had higher nitrate levels early in the season but after mid-July no differences were seen. The limited rainfall in July and August (Table 4) contributed to the limited amount of $\mathrm{N}$ release from the cover crops. Though the peak soil nitrate levels were higher in Columbus than in Fremont (in the conventional and integrated system), they remained above 5 to $10 \mu \mathrm{g}^{-} \mathrm{g}^{-}$ ${ }^{1}$ longer in Fremont. In general, tomato N uptake increases steadily from transplanting through flowering and fruit set, at which time there is a steady decline until there is no additional vegetative growth. Tomato plants are not very efficient users of applied fertilizer $\mathrm{N}$ and were found to absorb only $25 \%$ of total plant nitrogen from applied fertilizer, obtaining the rest from soil residual N (Hills et al., 1983). Low efficiency of fertilizer use by tomatoes occurs even with small initial residual $\mathrm{N}$ concentrations in the soil (Miller et al., 1981). An inefficient, poorly developed upper root system in tomato was offered as an explanation for a low recovery rate of applied fertilizer $\mathrm{N}$ (Jackson and Bloom, 1990). Tomato growth and development could therefore benefit from the $\mathrm{N}$ released from the deep decomposing cover-crop roots and possible increased root development in upper soil profiles with cover-crop residue mulch.

Mulch systems (integrated, organic, and no-input) had higher soil moisture levels than the conventional system for between 2 and 4 weeks after adequate rainfall ceased in early July (Fig. 2). Thus, moisture conservation is an important aspect of covercrop mulch systems when dry conditions occur, as most of the processing tomato production in Ohio occurs on nonirrigated land. Cover-crop mulches help to maintain higher soil moisture levels by enhancing infiltration (Griffith et al., 1986), and reducing evaporation (Phillips, 1981). A mulch may have little effect in an extended drought (Bond and Willis, 1969).

The presence of the cover-crop mulch did not reduce daily minimum soil temperatures, but did reduce the daily maximum soil temperatures (Fig. 3). Other studies have found the same reduction in diurnal temperature fluctuations from mulches (Ghuman and Lal, 1983; Teasdale and Mohler, 1993). Soil temperature reductions were most dramatic for mulched plots during the periods when air temperatures were highest (data not shown). An important outcome of this temperature depression is the reduction of weed seed germination for species that require diurnal temperature fluctuations to break dormancy. Taylorson (1987) reported that fluctuations up to 10C were generally required to break dormancy for such weed seeds, and the cover-crop mulch 
in this study reduced diurnal fluctuations to $<10 \mathrm{C}$.

Weed, insect, and disease variables. Overall, the cover-crop mulch suppressed annual broadleaf weeds and no additional weed control was necessary during the season. The cover-crop mulch reduced the number of annual broadleaves at both locations 2 and 4 weeks after planting (data not shown).

Broadleaf weed dry weights from the different systems were greatly reduced compared with the weedy check 6 and 12 weeks after transplanting (Fig. 4), and there were no differences between the conventional herbicide-treated plots and the mulch plots. Grass pressure was low in Columbus, and there were no differences in grass dry weights between systems in Fremont or Columbus. In the conventional system in Columbus, smallflower galinsoga (Galinsoga parviflora) was not controlled by the herbicides used in this study and accounted for the higher dry weights of broadleaves. In the Fremont area, eastern black nightshade (Solanum ptycanthum) is a problem for most growers, as it is not controlled by herbicides registered for use on tomatoes. The cover-crop mulch suppressed the smallflower galinsoga and eastern black nightshade (data not shown). The covercrop mulch kept the plots nearly weed free during the first 6 weeks after transplanting (Fig. 4). Friesen (1979) has shown that tomato fields kept weed free for 36 days yield similar amounts of tomatoes as fields kept weed free season long.

There were no differences in the frequency of scouted insect pests among the treatments (data not shown). Though some growers spray insecticides on a schedule, it is generally not necessary to spray for processing tomato pests in Ohio. In Columbus, insects were below threshold levels throughout the season. Tomato fruitworm exceeded the threshold once in Fremont so carbaryl was applied in the conventional and integrated plots, and Bacillus thuringiensis was applied in the organic plots. Beneficial insects [lady bugs (adults and larva) and parasitic wasps (larva)], and spiders, were not specifically monitored, but many were observed in the plots. In other studies (Bugg et al., 1990, 1991) winter annual cover crops have encouraged beneficial insects that can attack pests of succeeding crops.

Five fungicide sprays in Fremont and seven in Columbus, based on the TOMCAST disease forecasting system, were applied during the season to the conventional and integrated plots. However,
Columbus, $\mathrm{OH}$

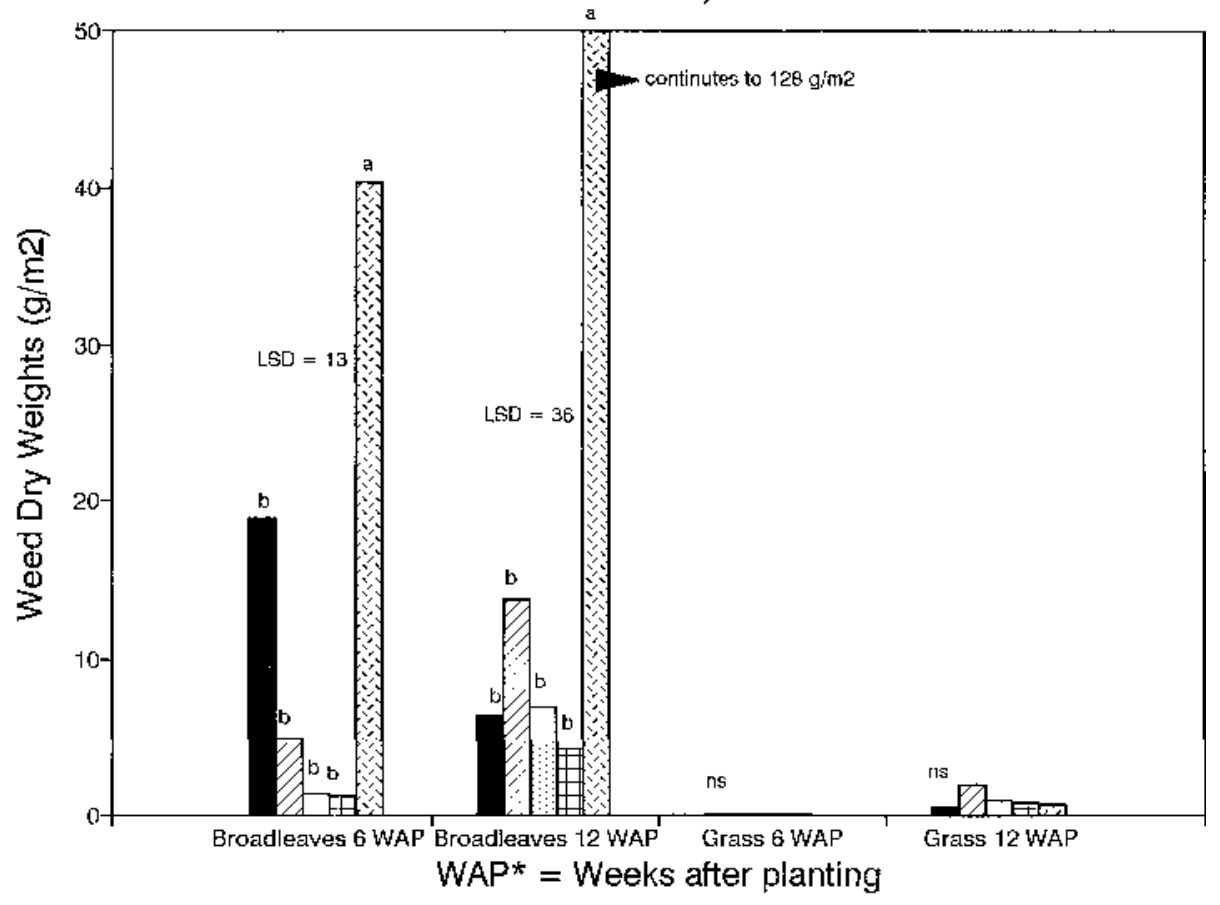

Fremont, $\mathrm{OH}$

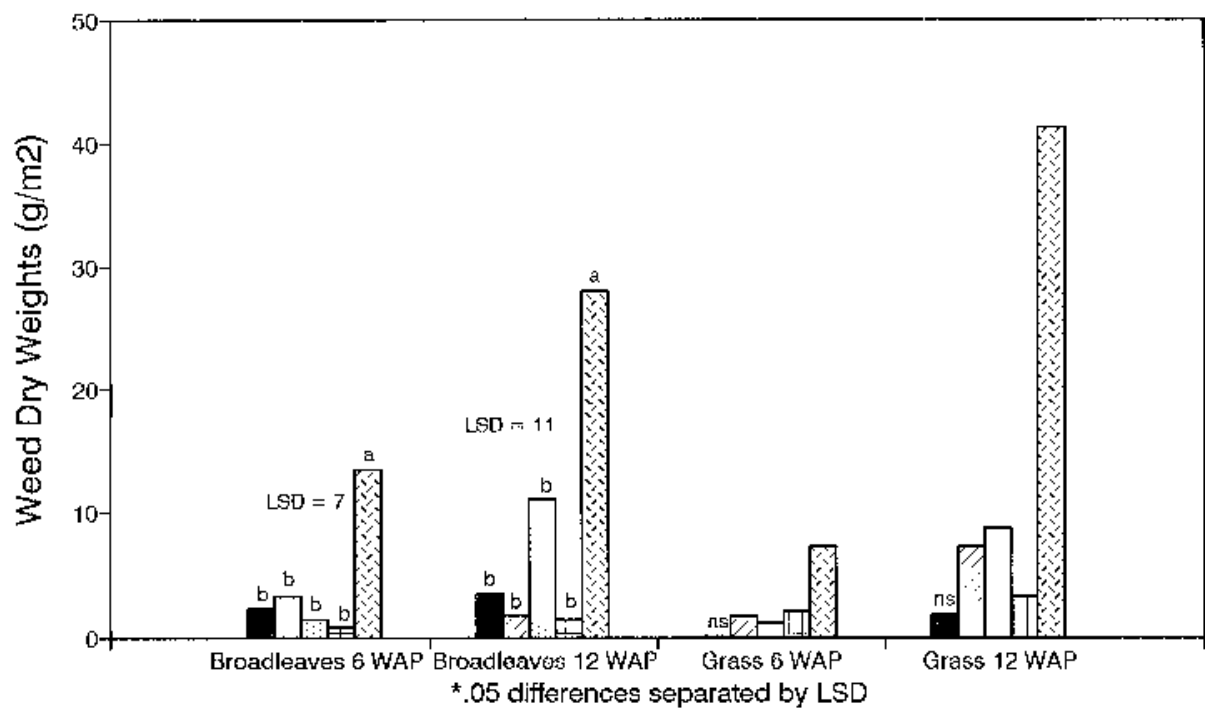

\begin{tabular}{|c|c|c|}
\hline Conventional & C/A Integrated & Orgenio \\
\hline No-Inpest & X Weedy Gheck & \\
\hline
\end{tabular}

Fig. 4. Influence of four processing tomato production systems on weed dry weights $\left(\mathrm{g} \cdot \mathrm{m}^{-2}\right)$ for broadleaves and grasses 6 and 12 weeks after planting in Columbus and Fremont, Ohio, 1993.

there were no differences in the incidence of early blight, Septoria, anthracnose, bacterial speck, or bacterial spot between the sprayed plots and the organic and no-input plots at either location. Blossom end rot was slightly higher in the conventional plots in Columbus (data not presented). After a rain, tomato plants in the conventional system were covered with rain-splashed soil whereas plants in the mulched plots were completely clean. For diseases transmitted 
Table 5. Economic analysis of variable costs of the conventional, integrated, organic, and no-input production systems at Columbus, Ohio, 1993.

\begin{tabular}{|c|c|c|c|c|c|c|c|c|c|}
\hline \multirow[b]{2}{*}{ Item } & \multicolumn{4}{|c|}{ Amount/ha } & \multirow[b]{2}{*}{ Price (\$)/unit } & \multicolumn{4}{|c|}{$\$ /$ ha } \\
\hline & Conventional & Integrated & Organic & No input & & Conventional & Integrated & Organic & No input \\
\hline \multicolumn{10}{|l|}{ Fertilizer } \\
\hline Starter & 46.8 liters & 46.8 liters & --- & --- & 0.29/liter & 13.57 & 13.57 & --- & --- \\
\hline Starter (organic) & --- & --- & $2.7 \mathrm{~kg}$ & --- & $10.67 / \mathrm{kg}$ & --- & --- & 28.81 & --- \\
\hline Nitrogen & $78.4 \mathrm{~kg}$ & $39.2 \mathrm{~kg}$ & --- & --- & $0.48 / \mathrm{kg}$ & 37.63 & 18.81 & --- & --- \\
\hline Phosphorus & $156.8 \mathrm{~kg}$ & $39.2 \mathrm{~kg}$ & --- & --- & $0.55 / \mathrm{kg}$ & 86.24 & 43.12 & --- & --- \\
\hline Potassium & $156.8 \mathrm{~kg}$ & $78.4 \mathrm{~kg}$ & --- & --- & $0.26 / \mathrm{kg}$ & 40.77 & 20.38 & --- & --- \\
\hline Foliar fish & --- & --- & $10.1 \mathrm{~kg}$ & --- & $5.27 . \mathrm{kg}$ & --- & --- & 53.23 & --- \\
\hline Seaweed extract & --- & --- & $0.7 \mathrm{~kg}$ & --- & $16.10 / \mathrm{kg}$ & --- & --- & 11.27 & --- \\
\hline \multicolumn{10}{|l|}{ Cover-crop seed } \\
\hline Hairy vetch & --- & $22.4 \mathrm{~kg}$ & $22.4 \mathrm{~kg}$ & $22.4 \mathrm{~kg}$ & $1.32 / \mathrm{kg}$ & --- & 29.57 & 29.57 & 29.57 \\
\hline Rye & --- & $26.9 \mathrm{~kg}$ & $26.9 \mathrm{~kg}$ & $26.9 \mathrm{~kg}$ & $0.31 / \mathrm{kg}$ & --- & 8.34 & 8.34 & 8.34 \\
\hline Barley & --- & $26.9 \mathrm{~kg}$ & $26.9 \mathrm{~kg}$ & $26.9 \mathrm{~kg}$ & $0.31 / \mathrm{kg}$ & --- & 8.34 & 8.34 & 8.34 \\
\hline Crimson clover & --- & $11.2 \mathrm{~kg}$ & $11.2 \mathrm{~kg}$ & $11.2 \mathrm{~kg}$ & $1.52 / \mathrm{kg}$ & --- & 17.02 & 17.02 & 17.02 \\
\hline \multicolumn{10}{|l|}{ Herbicide } \\
\hline Trifluralin & 2.30 liters & --- & --- & --- & 8.48/liter & 19.50 & --- & --- & --- \\
\hline Sencor & $0.4 \mathrm{~kg}$ & --- & --- & --- & $55.12 / \mathrm{kg}$ & 22.05 & --- & --- & --- \\
\hline \multicolumn{10}{|l|}{ Fungicide } \\
\hline Kocide & $6.7 \mathrm{~kg}$ & $3.36 \mathrm{~kg}$ & --- & --- & $4.63 / \mathrm{kg}$ & 31.02 & 15.55 & --- & --- \\
\hline Bravo & 21 liters & 10.37 liters & --- & --- & 12.43/liter & 261.02 & 128.89 & --- & --- \\
\hline \multicolumn{10}{|l|}{ Insecticide } \\
\hline Sevin & --- & --- & --- & --- & --- & --- & --- & --- & --- \\
\hline $\mathrm{Bt}$ & --- & --- & --- & --- & --- & --- & --- & --- & --- \\
\hline \multicolumn{10}{|l|}{ Custom application } \\
\hline Fertilizer & 1 appl. & 1 appl. & --- & --- & 7.41/appl. & 7.41 & 7.41 & --- & --- \\
\hline Foliar fertilizer & -- & --- & 3 appl. & --- & 13.59/appl. & --- & --- & 40.77 & --- \\
\hline Herbicide incorporation & n 1 appl. & --- & -- & --- & 35.82/appl. & 35.82 & --- & -- & --- \\
\hline Fungicide & 8 appl. & 8 appl. & --- & --- & 13.59/appl. & 108.72 & 108.72 & --- & --- \\
\hline Insecticide & -- & -- & --- & --- & --- & --- & --- & --- & --- \\
\hline Seeding cover crop & --- & 1 appl. & 1 appl. & 1 appl. & 29.64/appl. & --- & 29.64 & 29.64 & 29.64 \\
\hline Undercutting & --- & 1 appl. & 1 appl. & 1 appl. & 29.64/appl. & --- & 29.64 & 29.64 & 29.64 \\
\hline Total variable costs & & & & & & 663.76 & 479.01 & 256.55 & 122.55 \\
\hline Receipts $^{\mathrm{z}}$ & & & & & & 2731.82 & 2215.59 & 2285.29 & 2208.85 \\
\hline Return above variable costs & & & & & & 2068.06 & 1736.58 & 2028.64 & 2086.30 \\
\hline
\end{tabular}

${ }^{\mathrm{z}}$ Based on $\$ 76.04 / \mathrm{t}$ for conventional and $\$ 87.44 / \mathrm{t}$ for organic tomatoes.

yNo significant differences $(P=0.05)$.

partially by soil splashing onto the plants (e.g., Alternaria and anthracnose), the mulch may help to reduce their incidence.

Economic analysis. There were no significant differences in economic return above variable costs at Columbus (Table 5). In Fremont, the conventional system had a higher return/hectare (\$4315) than the other systems (Table 6). Though the level of chemical inputs was reduced in the integrated system, the applications still had to be made, which substantially added to the cost of the integrated system. In addition, there was the additional cost of seeding and undercutting the cover crop compared to the conventional system. The key difference between the organic and noinput was the foliar fish-seaweed applications, and in this study the applications did not translate to higher returns.

Cover crops can be managed in various ways in vegetable crop production systems. This method of undercutting the cover-crop mixture and leaving the residue intact on the soil surface as a mulch has several potential benefits. Cover-crop residue suppressed annual broadleaf and grass weeds in these experiments as effectively as the herbicides used in conventional systems. Organic and other vegetable growers seeking to reduce purchased inputs generally view weed management as the biggest problem they face, and this cover-crop management system may be a partial answer to their problem. In general, the tomatoes planted into the mulch looked vigorous throughout the growing season. The fact that all cover-crop treatment plots had minimal foliar or fruit disease incidence is encouraging, and the ability of the mulch to reduce soil splashing onto the leaves most likely plays a role in this.

Although this was only a 1-year study, the two locations were separated by $>100$ miles and provided the opportunity to quantify differences in two distinct environments. Comparing rainfall averages for the year of the study to long term averages showed a much wetter than average 16 June-15 July in Columbus, and a significantly drier than average August at both sites (Table 4). However, the differences in precipitation between Columbus and Fremont for the study year were actually larger in four of the nine 2-week segments than differences in precipitation at Columbus between 1993 and 1994 (data not shown). This illustrates that though the test was conducted in only 1 year, the variability between the two environments (Columbus and Fremont) was almost as great as if the test had been conducted in 1993 and 1994 in Columbus. Future studies will determine if some of the benefits in this study, for example, reduced tomato disease incidence, will be a consistent benefit when producing tomatoes and other vegetables in a dead cover-crop mulch. More study is also needed to determine opti- 
Table 6. Economic analysis of variable costs of the conventional, integrated, organic, and no-input production systems at Fremont, Ohio, 1993.

\begin{tabular}{|c|c|c|c|c|c|c|c|c|c|}
\hline \multirow[b]{2}{*}{ Item } & \multicolumn{4}{|c|}{ Amount/ha } & \multirow[b]{2}{*}{ Price (\$)/unit } & \multicolumn{4}{|c|}{$\$ /$ ha } \\
\hline & Conventional & Integrated & Organic & No input & & Conventional & Integrated & Organic & No input \\
\hline \multicolumn{10}{|l|}{$\overline{\text { Fertilizer }}$} \\
\hline Starter & 46.8 liters & 46.8 liters & --- & --- & 0.29/liter & 13.57 & 13.57 & --- & --- \\
\hline Starter (organic) & --- & --- & $2.7 \mathrm{~kg}$ & --- & $10.67 / \mathrm{kg}$ & --- & --- & 28.81 & --- \\
\hline Nitrogen & $78.4 \mathrm{~kg}$ & $39.2 \mathrm{~kg}$ & --- & --- & $0.48 / \mathrm{kg}$ & 37.63 & 18.82 & --- & --- \\
\hline Phosphorus & $156.8 \mathrm{~kg}$ & $78.4 \mathrm{~kg}$ & --- & --- & $0.55 / \mathrm{kg}$ & 86.24 & 43.12 & --- & --- \\
\hline Potassium & $156.8 \mathrm{~kg}$ & $78.4 \mathrm{~kg}$ & --- & --- & $0.26 / \mathrm{kg}$ & 40.77 & 20.38 & --- & --- \\
\hline Foliar fish & --- & --- & $10.1 \mathrm{~kg}$ & --- & $5.27 / \mathrm{kg}$ & --- & --- & 53.23 & --- \\
\hline Seaweed extract & --- & --- & $0.7 \mathrm{~kg}$ & --- & $16.10 / \mathrm{kg}$ & --- & --- & 11.27 & --- \\
\hline \multicolumn{10}{|l|}{ Cover-crop seed } \\
\hline Hairy vetch & --- & $22.4 \mathrm{~kg}$ & $22.4 \mathrm{~kg}$ & $22.4 \mathrm{~kg}$ & $1.32 / \mathrm{kg}$ & --- & 29.57 & 29.57 & 29.57 \\
\hline Rye & --- & $26.9 \mathrm{~kg}$ & $26.9 \mathrm{~kg}$ & $26.9 \mathrm{~kg}$ & $0.31 / \mathrm{kg}$ & --- & 8.34 & 8.34 & 8.34 \\
\hline Barley & --- & $26.9 \mathrm{~kg}$ & $26.9 \mathrm{~kg}$ & $26.9 \mathrm{~kg}$ & $0.31 / \mathrm{kg}$ & --- & 8.34 & 8.34 & 8.34 \\
\hline Crimson clover & --- & $11.2 \mathrm{~kg}$ & $11.2 \mathrm{~kg}$ & $11.2 \mathrm{~kg}$ & $1.52 / \mathrm{kg}$ & --- & 17.02 & 17.02 & 17.02 \\
\hline \multicolumn{10}{|l|}{ Herbicide } \\
\hline Trifluralin & 2.30 liters & --- & --- & --- & 8.48/liter & 19.50 & --- & --- & --- \\
\hline Sencor & $0.4 \mathrm{~kg}$ & --- & --- & --- & $55.12 / \mathrm{kg}$ & 22.05 & --- & --- & --- \\
\hline \multicolumn{10}{|l|}{ Fungicide } \\
\hline Kocide & $16.8 \mathrm{~kg}$ & $8.4 \mathrm{~kg}$ & --- & --- & $4.63 / \mathrm{kg}$ & 77.78 & 38.89 & --- & --- \\
\hline Bravo & 17.5 liters & 8.7 liters & --- & --- & 12.43/liter & 217.52 & 108.14 & --- & --- \\
\hline \multicolumn{10}{|l|}{ Insecticide } \\
\hline Sevin & 4.67 liters & 4.67 liters & --- & --- & 6.89/liter & 32.18 & 32.18 & --- & --- \\
\hline $\mathrm{Bt}$ & --- & --- & 7.0 liters & --- & 6.89/liter & --- & --- & 48.23 & --- \\
\hline \multicolumn{10}{|l|}{ Custom application } \\
\hline Fertilizer & 1 appl. & 1 appl. & --- & --- & 7.41/appl. & 7.41 & 7.41 & --- & --- \\
\hline Foliar fertilizer & --- & --- & 3 appl. & --- & 13.59/appl. & --- & --- & 40.77 & --- \\
\hline Herbicide incorporation & n 1 appl. & --- & -- & --- & 35.82/appl. & 35.82 & --- & --- & --- \\
\hline Fungicide & 5 appl. & 5 appl. & --- & --- & 13.59/appl. & 67.95 & 67.95 & --- & --- \\
\hline Insecticide & 1 appl. & 1 appl. & 1 appl. & --- & 13.59/appl. & 13.59 & 13.59 & 13.59 & --- \\
\hline Seeding cover crop & -- & 1 appl. & 1 appl. & 1 appl. & 29.64/appl. & --- & 29.64 & 29.64 & 29.64 \\
\hline Undercutting & --- & 1 appl. & 1 appl. & 1 appl. & 29.64/appl. & --- & 29.64 & 29.64 & 29.64 \\
\hline Total variable costs & & & & & & 671.87 & 486.60 & 301.25 & 122.55 \\
\hline Receipts $^{z}$ & & & & & & 4986.93 & 3357.47 & 3042.81 & 3184.92 \\
\hline Return above variable costs & & & & & & 4315.06 & 2870.87 & 2742.56 & 3062.37 \\
\hline
\end{tabular}

${ }^{\mathrm{z}}$ Based on $\$ 76.04 / \mathrm{t}$ for conventional and $\$ 87.44 / \mathrm{t}$ for organic tomatoes.

$\mathrm{y}_{\text {LSD }}(0.05)=\$ 817.28$.

mum $\mathrm{N}$ rates, optimum source of $\mathrm{N}$, and the best method of application for all systems. As is common when transitioning from a conventional system to an organic system of production, improvements in soil physical, chemical, and biological properties may also lead to increased yields after 4 to 5 years.

\section{Literature Cited}

Abdul-Baki, A.A. and J.R. Teasdale. 1993. A no-tillage tomato production system using hairy vetch and subterranean clover mulches. HortScience 28:106-109.

Agboola, A.A. and A.A. Fayemi. 1972. Fixation and excretion of nitrogen by tropical legumes. Agron. J. 64:409-412.

Allison, F.E. 1966. The fate of nitrogen applied to soils. Adv. Agron. 18:219-258.

Altieri, M.A. and D.K. Letourneau. 1982. Vegetation management and biological control in agroecosystems. Crop Prot. 1:405-430.

Andow, D.A. 1988. Management of weeds for insect manipulation in agroecosystems, p. 265-294. In M.A. Altieri and M. Liebman (eds.). Weed management in agroecosystems: Ecological approaches. CRC Press, Boca Raton, Fla.

Berry, S.Z., M. R. Uddin, W.A. Gould, A.D. Bisges, and G.D. Dyer. 1988. Stability in fruit yield, soluble solids, and citric acid of eight machineharvested processing tomato cultivars in northern Ohio. J. Amer. Soc.
Hort. Sci. 113:604-608.

Beste, C.E. 1973. Evaluation of herbicides in no-till planted cucumbers, tomatoes, and lima beans. NE Weed Sci. Soc. Proc. 27:232-239.

Blevins, R.L., G.W. Thomas, and P.L. Cornelius. 1977. Influence of notillage and nitrogen fertilization on certain soil properties after 5 years of continuous corn. Agron. J. 69:383-386.

Bond, J.J. and W.O. Willis. 1969. Soil water evaporation: Surface residue rate and placement effects. Soil Sci. Soc. Amer. Proc. 33:445-448.

Boosalis, M.G. and G.E. Cook. 1973. Plant diseases, p. 114-125. In: Conservation tillage, conference proceedings. Soil Conservation Soc. Amer., Ankeny, Iowa.

Broadbent, F.E. 1984. Plant use of soil nitrogen. In: R.D. Hauck (ed.). Nitrogen in crop production. Amer. Soc. Agron., Crop Sci. Soc. Amer., Soil Sci. Soc. Amer., Madison, Wis.

Bugg, R.L., S.C. Phatak, and J.D. Dutcher. 1990. Insects associated with cool-season cover crops in southern Georgia: Implications for biological control in truck-farm and pecan agroecosystems. Biol. Agr. Hort. 7:1745.

Bugg, R.L., F.L. Wackers, K.E. Brunson, J.D. Dutcher, and S.C. Phatak. 1991. Cool-season cover crops relay intercropped with cantaloupe: Influence on a generalistic predator, Geocoris punctipes (Hemiptera: Lygaeidae). J. Econ. Entomol. 84:408-415.

Creamer, N.B., B. Plassman, M.A. Bennett, R.K. Wood, B.R. Stinner, and J. Cardina. 1995. A method for mechanically killing cover crops to 
optimize weed suppression. J. Alt. Agr. 10:156-161.

Doss, B.D., J.L. Turner, and C.E. Evans. 1981. Influence of tillage, nitrogen, and rye cover crop on growth and yield of tomatoes. J. Amer. Soc. Hort. Sci. 106:95-97.

Exner, D.N. and R.M. Cruse. 1993. Interseeded forage legume potential as winter ground cover, nitrogen source and competitor. J. Prod. Agr. 6:226-231.

Fawcett, R.S. 1987. Overview of pest management for conservation tillage systems, p. 17-37. In: T.J. Logan (ed.). Effects of conservation tillage on groundwater quality: Nitrates and pesticides, Lewis Publishers, Chelsea, Mich.

Flach, K.W. 1990. Low-input agriculture and soil conservation. J. Soil Water Conservation 45:42-47.

Fortin, M.C. and F.J. Pierce. 1991. Timing and nature of mulch retardation of corn vegetative development. Agron. J. 83:258-263.

Friesen, G.H. 1979. Weed interference in transplanted tomatoes (Lycopersicon esculentum). Weed Sci. 27:11-13.

Gardner, W.H. 1986. Water content, p. 493-544. In: A. Klute (ed.). Methods of soil analysis part 1-Physical and mineralogical methods. 2nd ed. Amer. Soc. Agron., Soil Sci. Soc. Amer., Madison, Wis.

Ghuman, B.S. and R. Lal. 1983. Effect of cover crop on temperature regime of an Alfisol in the tropics. Agron. J. 75:931-936.

Griffith, D.R., J.B. Mannering, and J.E. Box. 1986. Soil and moisture management with reduced tillage, p. 19-55. In: M.A. Sprague and G.B. Triplett (eds.). No-tillage and surface-tillage agriculture. Wiley, New York.

Hills, F.J., F.E. Broadbent, and O.A. Lorenz. 1983. Fertilizer nitrogen utilization by corn, tomato and sugarbeet. Agron. J. 75:423-426.

Hoyt, G.D. and W.L. Hargrove. 1986. Legume cover crops for improving crop and soil management in the southern United States. HortScience 21:397-402.

Hoyt, G.D., D.W. Monks, and T.J. Monaco. 1994. Conservation tillage for vegetable production. Hort Technology 4:129-135.

Jackson, L.E. and A.J. Bloom. 1990. Root distribution in relation to soil nitrogen availability in field-grown tomatoes. Plant Soil 128:115-126.

Jones, Jr., J.B. and V.W. Case. 1990. Sampling, handling, and analyzing plant tissue samples, p. 389-428. In: R.L. Westerman. (ed.). Soil testing and plant analysis. 3rd ed. Soil Sci. Soc. Amer., Madison, Wis.

Keeney, D.R. and D.W. Nelson. 1982. Nitrogen-inorganic forms, p. 643 698. In: A.L. Page, R.H. Miller, and D.R. Keeney (eds.). Methods of soil analysis part 2-Chemical and microbiological properties. 2nd ed. Amer. Soc. Agron., Soil Sci. Soc. Amer., Madison, Wis.

Kommedahl, T. 1984. Interaction of nitrogen use and plant disease control. In: R.D. Hauck (ed.) Nitrogen in crop production. Amer. Soc. Agron., Crop Sci. Soc. Amer., Soil Sci. Soc. Amer., Madison, Wis.

Merriman, P.R., M. Pywell, G. Harrison, and J. Nancarrow. 1979. Survival of sclerotia of Sclerotinia sclerotiorum and effects of cultivation practices on disease. Soil Biol. Biochem. 11:567-570.

McVay, K.A., D.E. Radcliffe, and W.L. Hargrove. 1989. Winter legume effects on soil properties and nitrogen fertilizer requirements. Soil Sci. Soc. Amer. J. 53:1856-1862.

Miller, R.J., D.E. Rolston, R.S. Rauschkolb, and D.W. Wolfe. 1981. Labelled nitrogen uptake by drip-irrigated tomatoes. Agron. J. 73:265270.

National Research Council, Board on Agriculture. 1989. Alternative agriculture. Natl. Acad. Sci., Washington, D.C.

Nelson, D.W. and L.E. Summers. 1982. Total carbon, organic carbon, and organic matter, p. 539-579. In: A.L. Page, R.H. Miller, and D.R. Keeney (eds.). Methods of soil analysis part 2-Chemical and microbiological properties. 2nd ed. Amer. Soc. Agron., Crop Sci. Soc. Amer., Soil Sci. Soc. Amer., Madison, Wis.

NeSmith, D.S., G. Hoogenboom, and D.V. McCracken. 1994. Summer squash production using conservation tillage. HortScience 29:28-30.

Ohio Ecological Food and Farming Association. 1992. Organic certification standards. OEFFA, Columbus.

Ofori, C.F. and W.R. Stern. 1987. Cereal-legume intercropping systems. Adv. Agron. 26:177-204.

Phatak, S.C., R.L. Bugg, D.R. Sumner, J.D. Gay, K.E. Brunson, and R.B. Chalfant. 1990. Cover crops in IPM of weeds, diseases and insects of vegetables. In: Abstracts XXIII international horticulture congress, Firenze.

Phillips, R.E. 1981. Soil moisture, p. 23-42. In: R.E. Phillips, G.W. Thomas, and R.L. Blevins (eds.). No-tillage research reports and reviews. Univ. of Kentucky, Lexington.

Phillips, S.H. 1984. Other pests in no-tillage and their control, p. 171-189. In: R.E. Phillips and S.H. Phillips (ed). No tillage agriculture. Van Nostrand Reinhold Co., New York.

Pitblado, R.E. 1988. Development of a weather-timed fungicide spray program for field tomatoes. Can. J. Plant Pathol. 10:371. (Abstr.)

Price, H.C. and R.A. Baughan. 1987. Establishment of fresh market tomatoes in a no-till system. Acta Hort. 198:261-268.

Putnam, A.R. 1988. Allelopathy: Problems and opportunities in weed management, p. 77-86. In: M.A. Altieri and M. Liebman (eds.). Weed management in agroecosystems: Ecological approaches. CRC Press, Boca Raton, Fla.

Rice, E.L. 1974. Allelopathy. Academic Press, New York.

Roberts, B.W. and B. Cartwright. 1991. Cover crop, nitrogen, and insect interactions, p. 164-167. In: W.L. Hargrove (ed.). Cover crops for clean water. Soil Water Conservation Soc., Ankeny, Iowa.

Shelby, Jr., P.P., D.L. Coffey, G.N. Rhodes, Jr., and L.S. Jeffery. 1988. Tomato production and weed control in no-tillage versus conventional tillage. J. Amer. Soc. Hort. Sci. 113:675-678.

Stern, V.M , R. van den Bosch, R.G. Leigh, O.D. McCutcheon, W.R. Sallee, W.R. Houston, and M.J. Garber. 1967. Lygus control by strip cutting alfalfa. Univ. of California Agr. Ext. Serv. Hdbk. AXT-241.

Stevens, M.A. and J. Rudich. 1978. Genetic potential for overcoming physiological limitations on adaptability, yield, and quality in the tomato. HortScience 13:673-677.

Stivers, L.J. and C. Shennan. 1989. Winter cover cropping in processing tomato production, p. 254. (Abstr.). Amer. Soc. Agron., Crop Sci. Soc. Amer., Soil Sci. Soc. Amer., Madison, Wis.

Sumner, D.R., E.D. Threadgill, D.A. Smittle, S.C. Phatak, and A.W. Johnson. 1986. Conservation tillage and vegetable diseases. Plant Dis. 70(10):906-911.

Taylorson, R.B. 1987. Environmental and chemical manipulation of weed seed dormancy. Rev. Weed Sci. 3:135-154.

Teasdale, J.R. 1993. Interaction of light, soil moistures, and temperature with weed suppression by hairy vetch residue. Weed Sci. 41:46-51.

Teasdale, J.R. and C.L. Mohler. 1993. Light transmittance, soil temperature, and soil moisture under residue of hairy vetch and rye. Agron. J. 85:673-680.

Wagger, M.G. 1987. Timing effects of cover crop desiccation on decomposition rates and subsequent nitrogen uptake by corn, p. 35-37. In: J.F. Power (ed.) The role of legumes in conservation tillage systems. Soil Conservation Soc. Amer., Ankeny, Iowa.

Wilkinson, L. 1990. SYSTAT: The system for statistics. SYSTAT, Inc., Evanston, Ill. 